\title{
Lababitha nom.n., a replacement name for Mystes Bristowe, 1938, with a redescription of the type species (Aranei: Filistatidae)
}

\section{Lababitha nom.n., замещающее название дмя Mystes Bristowe, 1938, с переописанием типового вида (Aranei: Filistatidae)}

\author{
Sergei L. Zonstein ${ }^{1}$, Yuri M. Marusil ${ }^{2-4}$, Ivan L.F. Magalhaes ${ }^{5}$

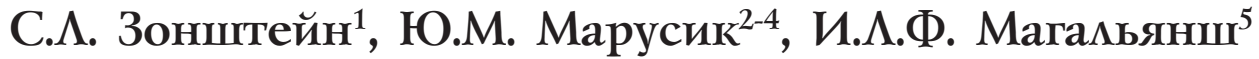

\footnotetext{
${ }^{1}$ Steinhardt Museum of Natural History, Tel-Aviv University, 69978 Tel-Aviv, Israel. E-mail: znn@post.tau.ac.il

${ }^{2}$ Institute for Biological Problems of the North RAS, Portovaya Str. 18, Magadan, Russia. E-mail: yurmar@mail.ru

${ }^{3}$ Department of Zoology \& Entomology, University of the Free State, Bloemfontein 9300, South Africa.

${ }^{4}$ Zoological Museum, Biodiversity Unit, FI-20014 University of Turku, Finland.

${ }^{5}$ División Aracnología, Museo Argentino de Ciencias Naturales "Bernardino Rivadavia" - CONICET, Av. Ángel Gallardo 470, C1405DJR, Buenos Aires, Argentina. E-mail: magalhaes@macn.gov.ar

${ }^{2}$ Институт биологических проблем Севера, ДВО, Магадан 685000. Россия.
}

KEY WORDS: Araneae, Prithinae, spiders, homonymy, replacement name, Asia, Malaysia.

КЛЮЧЕВЫЕ СЛОВА: Araneae, Prithinae, пауки, старший омоном, замещающее название, диагноз, Азия, Малайзия.

ABSTRACT. The monotypic genus Mystes Bristowe, 1938, and its type species, M. oonopiformis Bristowe, 1938, are redescribed based on the neotype male (designated here) and several females. The male is described for the first time and the female endogyne is illustrated for the first time. Morphological analysis reveals that the genus belongs to the Prithinae and is close to the Australian genera Wandella Gray, 1994 and Yardiella Gray, 1994. As the name Mystes is preoccupied by Mystes Champion, 1895 (Coleoptera: Melandryidae), we propose Labahitha nom.n. as a replacement name.

How to cite this article: Zonstein S.L., Marusik Yu.M., Magalhaes I.L.F. 2017. Labahitha nom.n., a replacement name for Mystes Bristowe, 1938, with a redescription of the type species (Aranei: Filistatidae) // Arthropoda Selecta. Vol.26. No.4. P.303-309. doi: 10.15298/arthsel.26.4.04

РЕЗЮМЕ. Монотипичный род Mystes Bristowe, 1938, и его типовой вид M. oonopiformis Bristowe, 1938 переописываются по обозначенному здесь самцу-неотипу и нескольким самкам. Впервые для вида описываются самец и приводятся изображения эндогины самки. Морфологические признаки этого рода указывают на то, что он принадлежит к подсем. Prithinae и может быть близкородственным по отношению к Wandella Gray, 1994, и Yardiella Gray, 1994. Так как название Mystes преоккупировано родом Mystes Champion, 1895 (Coleoptera: Melandryidae), мы предлагаем Labahitha nom. n. как замещающее название.

\section{Introduction}

A monotypic genus Mystes Bristowe, 1938 was originally placed in the Pholcidae, subfamily Ninetinae [Bristowe, 1938]. Its type species, M. oonopiformis Bristowe, 1938, was described based only on the female holotype from Parit Buntar, Malaysia. Descriptions of both genus and species were supplied with drawings of several somatic characters, but the copulatory organs were not illustrated or indeed mentioned. Recently, Huber et al. [2014] transferred the genus into the Filistatidae. Although the holotype M. oonopiformis was not studied and is apparently lost [Huber et al. 2014], judging from the original description, it is clear, that this transfer was correct. Mystes oonopiformis features an eye pattern, shape of clypeus, chelicera and palpal tarsus as in the Filistatidae but not in the Pholcidae. Bonnet [1957: 3025] found the name Mystes to be a junior homonym of Mystes Champion, 1895 (Melandryidae), but a replacement name was not suggested neither by Bonnet [1957], nor Huber et al. [2014], because the identity of the type species had yet to be clarified.

In recent years, several filistatid genera have had their type species redescribed, including Zaitunia Lehtinen [Zonstein, 2008; Zonstein, Marusik, 2016], Pholcoides Roewer, 1960 [Zonstein et al., 2013], Tricalamus Wang, 1987 [Zonstein et al., 2016], Pritha Lehtinen, 1967 [Legittimo et al., 2017] and Filistatinella Gertsch et Ivie, 1936 [Magalhaes, Ramírez, in press]. This has enabled a more solid taxonomy for the Filistatidae at the generic level. However, some genera still remain to be better characterized, with Mystes at 

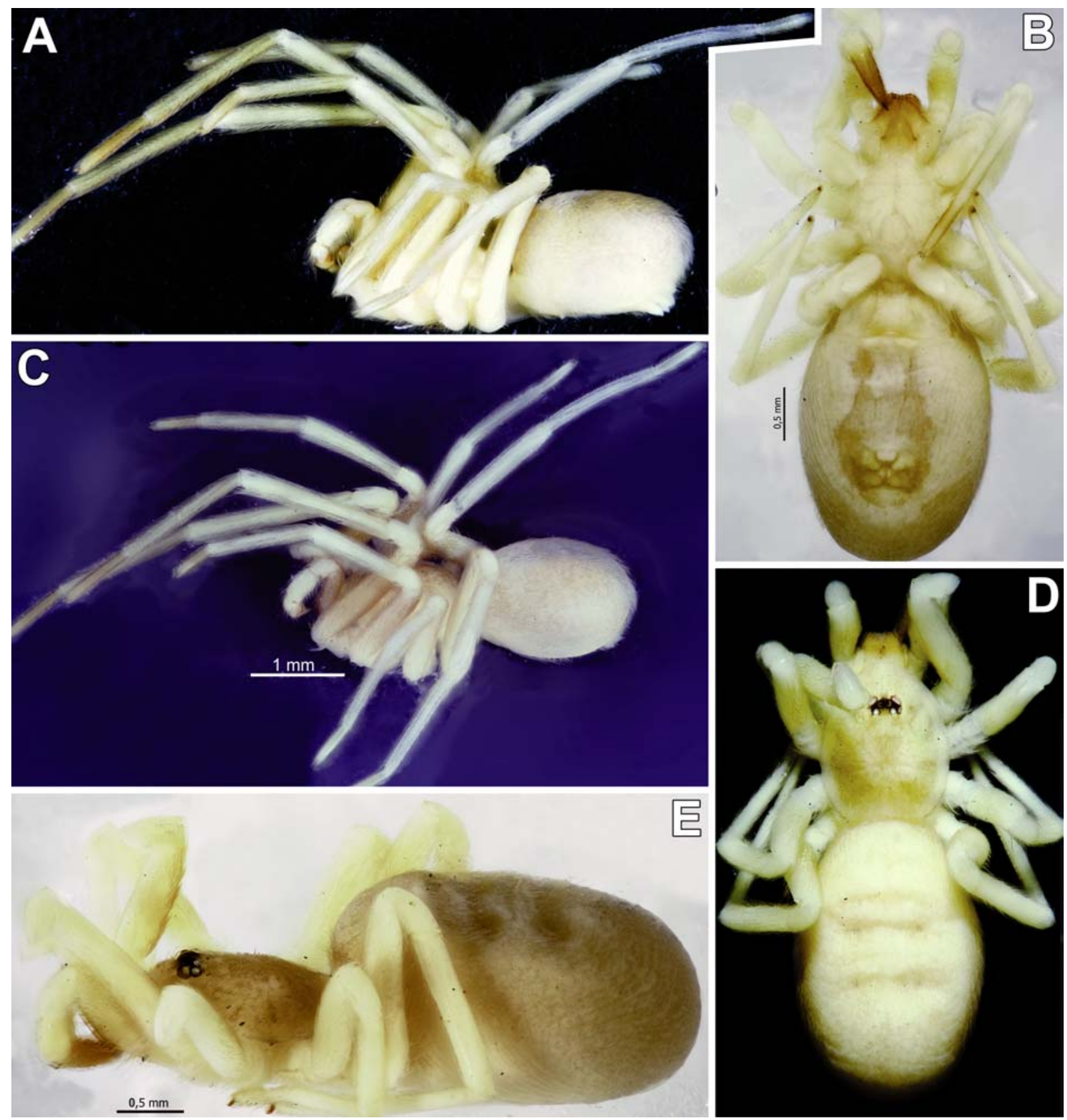

Fig. 1. Habitus of Labahitha oonopiformis. A - male, lateral; B - female, ventral; C - male, subdorsal; D-E - female, dorsal and lateral.

Рис. 1. Габитус Labahitha oonopiformis. А - самец, сбоку; В - самка, снизу; C - самец, сверху-сбоку; D-E — самка, сверху и сбоку.

the top of the list as one of the most enigmatic filistatids.

Upon studying Filistatidae samples from Murphy's collection stored in the Manchester Museum, we found several vials with adult filistatid specimens collected not too far from the type locality of $M$. oonopiformis. These specimens fit well to the description provided by Bristowe [1938] and hence we consider them as $M$. oonopiformis. The main aims of this article are: 1) to redescribe the female of this species; 2) to describe the internal structures of the female copulatory organs; $3)$ to describe the male for the first time; and 4) to evaluate the taxonomic status of the genus (i.e. to determine whether it has any synonyms or to provide a replacement name if no synonyms will be found).

\section{Material and Methods}

Specimens were photographed using a Canon EOS 7D camera attached to an Olympus SZX16 stereomi- 

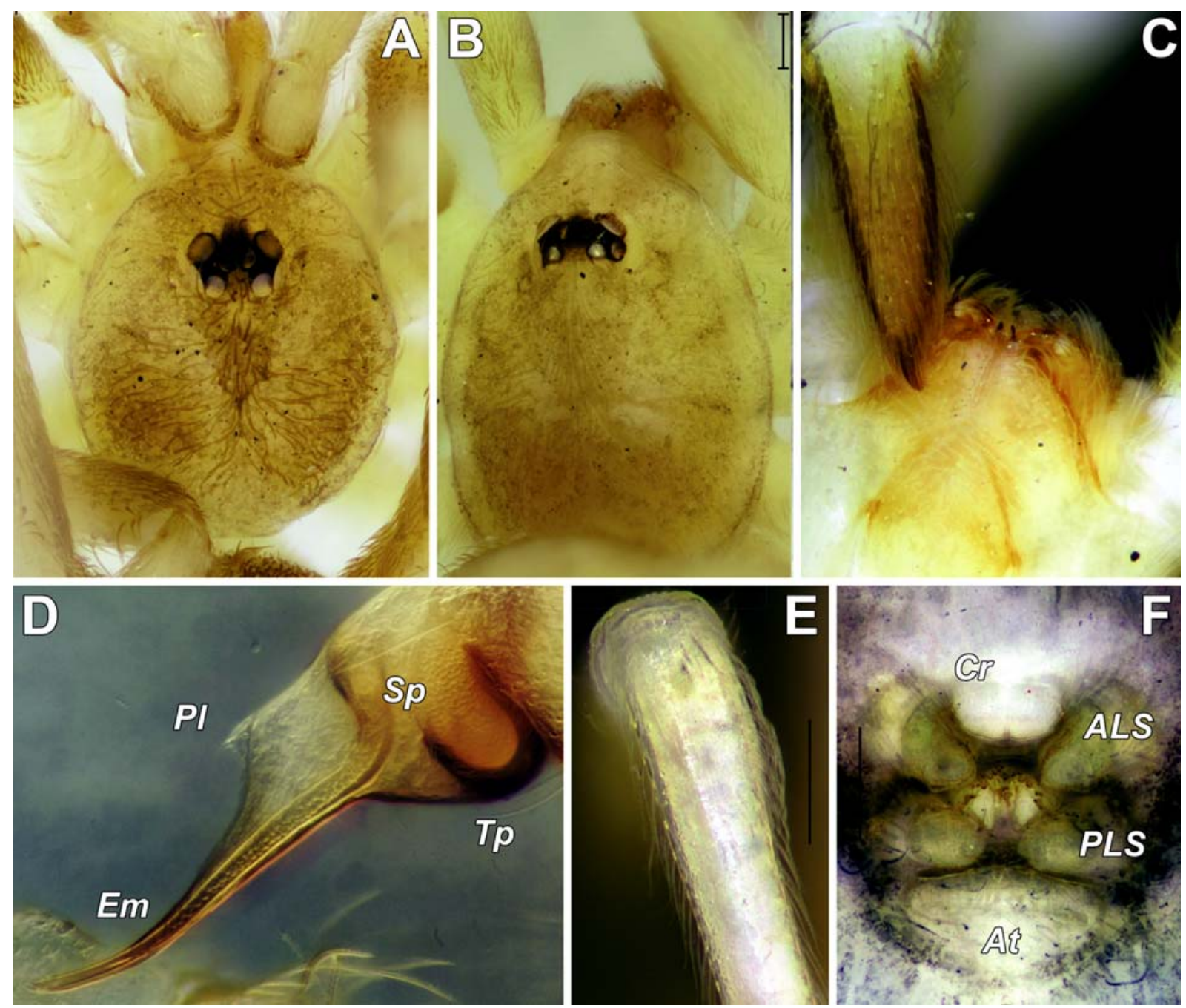

Fig. 2. Labahitha oonopiformis. A - male carapace, dorsal; B - female carapace, dorsal; C - female chelicerae and endites, ventral; D - bulb, retrolateral; E - left calamistrum, dorsal; F — female, spinnerets, ventral. Abbreviations: ALS — anterior lateral spinnerets, At - anal tubercle, $\mathrm{Cr}$ - cribellum, Em - embolus, Pl — paraembolic lamina, PLS - posterior lateral spinnerets, $\mathrm{Sp}$ - spermophore, $\mathrm{Tp}$ - tegular part of the bulb. Scale bars $=0.1 \mathrm{~mm}$.

Рис. 2. Labahitha oonopiformis. А - карапакс самца, сверху; В - карапакс самки, сверху; С - хелицеры самки и эндиты, снизу; D - бульбус, ретролатерально; Е - левый каламиструм, сверху; F - паутинные бородавки самки, снизу. Сокращения: ALS - передне-боковые бродавки, At - анальный бугорок, Cr - крибеллюм, Em - эмболюс, $\mathrm{Pl}$ - приэмболюсная мембрана, PLS - задние-боковые бородавки, Sp - спермофор, Тp - тегулярная часть бульбуса. Масштаб 0,1 мм.

croscope at the Zoological Museum, University of Turku, Finland. Digital images were montaged using CombineZP image stacking software. The vulva was cleanced in a $\mathrm{KOH} /$ water solution until the soft tissues were dissolved. Photographs were taken in dishes with cotton or paraffin on the bottom to secure the specimens. For scanning electron microscopy, specimens were passed through a series of solutions with increasing concentrations of ethanol (80-100\%), critical-point dried, attached to aluminium stubs using conductive copper tape, covered with a thin layer of gold-paladium, and examined under a Phillips FEI XL 30 TMP microscope under high vacuum at the Museo Argentino de Ciencias Naturales "Bernardino Rivadavia", Buenos Aires. All measurements are given in millimeters.
Abbreviations used in the text: ALE - anterior lateral eyes, $\mathrm{AME}$ - anterior median eyes, CAS California Academy of Sciences, MMUE - Manchester Museum, PLE - posterior lateral eyes, PME posterior median eyes.

\section{Taxonomy}

Family Filistatidae Ausserer, 1867

Subfamily Prithinae Gray, 1995

\section{Genus Labahitha nom.n.}

Mystes Bristowe, 1938: 319; Huber et al., 2014: 420 (transfer from Pholcidae to Filistatidae). Preoccupied in Melandryidae (Coleoptera) by Champion, 1895: 235 . 

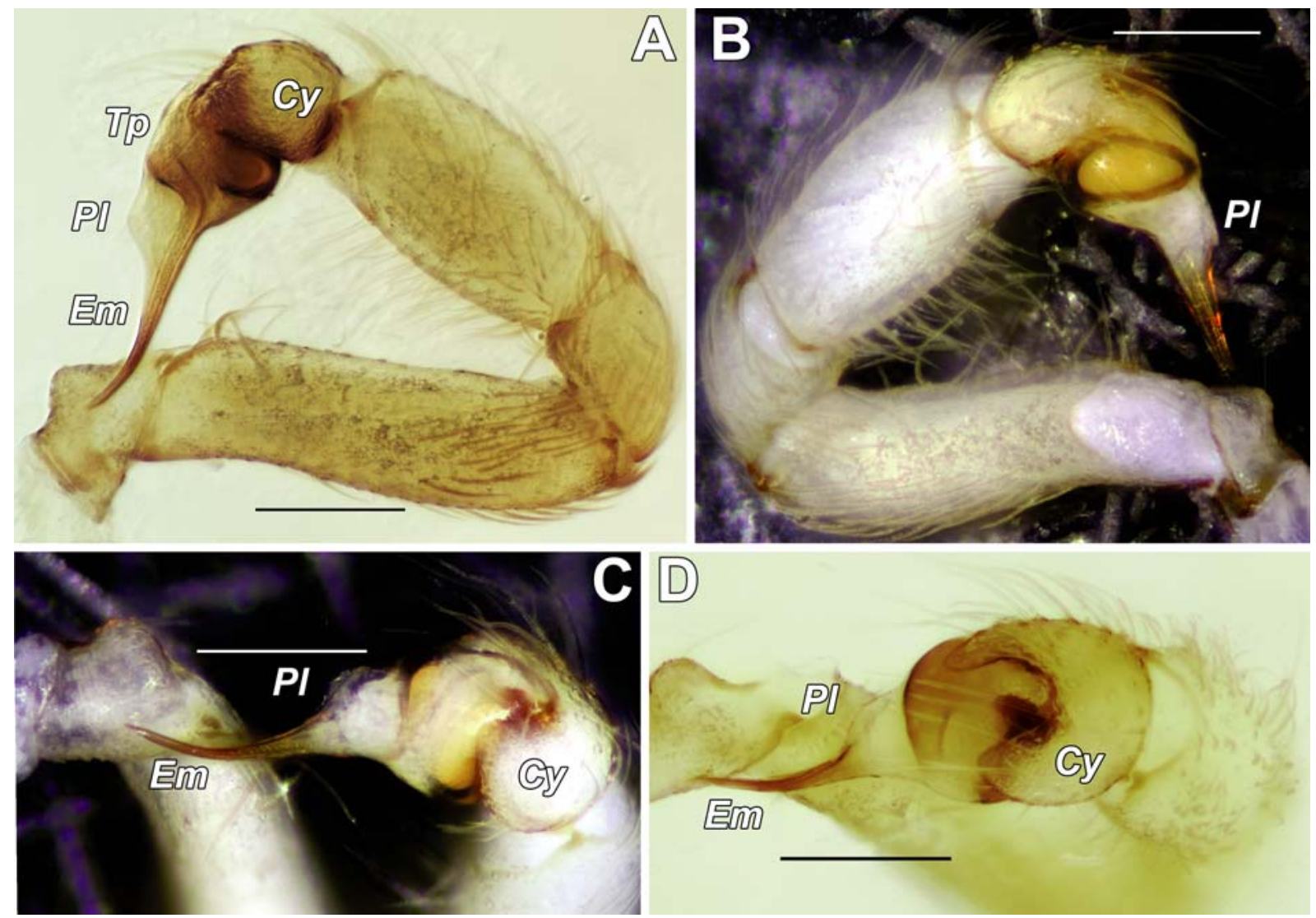

Fig. 3. Left male palp of Labahitha oonopiformis. A-B - palp, retrolateral and prolateral; C-D — bulb, subdorsal and dorsal. Abbreviations: Cy — cymbium, Em — embolic part, PL — paraembolic lamina, Sp — spermophore, Tp — tegular part of the bulb. Scale bars $=0.1 \mathrm{~mm}$.

Рис. 3. Левая пальпа самца Labahitha oonopiformis. A-B - пальпа, ретролатерально и пролатерально; C-D - бульбус, сверху-сбоку и сверху. Сокращения: Су — цимбиум, Em - эмболюсная часть, Pl — приэмболюсная мембрана, Sp - спермофор, Тр - тегулярная часть бульбуса. Масштаб 0,1 мм.

TYPE SPECIES: Mystes oonopiformis Bristowe, 1938, by monotypy.

ETYMOLOGY. The proposed name is a combination of labah-labah (Malay for "spider") and Pritha, in order to save and provide continuity and to exclude a homonymy. The gender is feminine.

DIAGNOSIS. Labahitha nom. n. male can be distinguished by the characteristic drop-shaped bulb, which displays a gently curved embolic part and has a keellike paraembolic lamina attached near the coil of the spermophor. Females are similar to those of Pritha, Wandella and Tricalamus, and the diagnosis is tentative and might change if further congeners are discovered. Labahitha females have the inner receptacles large, globose, ill-defined, with patches of pore glands loosely distributed. They further differ from Wandella by lacking contrasting coloration (Wandella has strong submarginal bands and leg annulations) and from Pritha and Tricalamus by lacking leg macrosetae.

REDESCRIPTION. Same as for species.

RELATIONSHIPS. Labahitha nom.n. is closely related to other genera of the Prithinae occurring from the Mediterranean region to Australasia: Pritha, Trica- lamus, Wandella and Yardiella (see Gray, 1995; Ramírez \& Grismado, 1997). This group of genera is characterized by a horseshoe-shaped cymbium in the male palp, absence of plumose setae, female genitalia with two pairs of receptacles and absence of aciniform gland spigots. Among these genera, Labahitha appears to be more closely related to Wandella and Yardiella. Putative synapomorphies uniting these three genera are the reduced spination of the legs (leg macrosetae are completely absent in females, as opposed to Pritha and Tricalamus; see Marusik \& Zamani, 2015; Magalhaes, 2016; Zonstein \& Marusik, 2016) and the possession of a paraembolic lamina associated to the male palp. In Wandella and Yardiella, the paraembolic lamina is variable in shape, but is usually erect or prolaterally curved and always has a free end [Gray, 1994; Magalhaes, 2016]. In Labahitha nom.n., the paraembolic lamina is reduced to a keel-like process with an attached end (Figs 2D, 3). We did not observe micro-teeth in $L$. oonopiformis, but scanning electron microscopy images of putative congeners from Singapore and Philippines reveal these structures (Fig. 4A) - another character shared with Wandella and Yardiella. Finally, SEM 

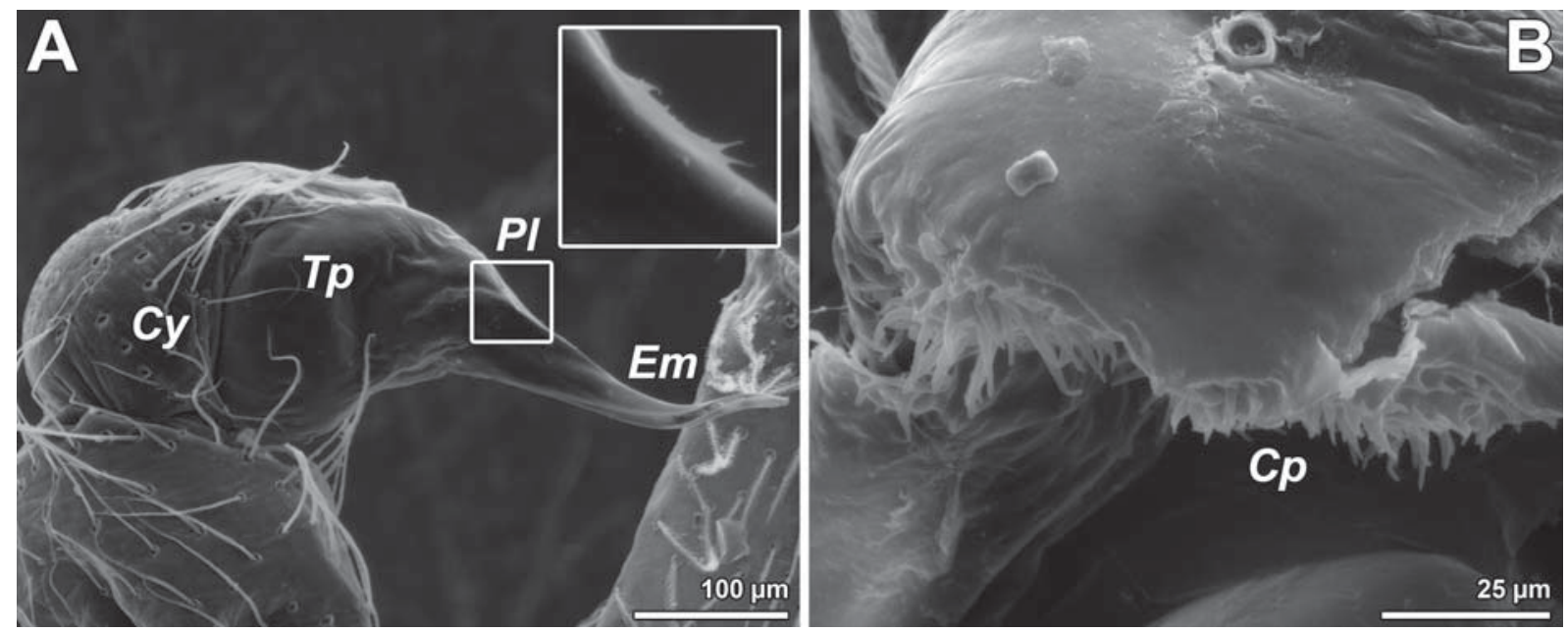

Fig. 4. Labahitha sp. from Philippines, Mindoro, San Jose (CAS 9060572). A — left bulb, prolateral; B — clypeus, anterior. Abbreviations: CP — clypeal projections, Cy — cymbium, Em — embolus, PL — paraembolic lamina, TP — tegular part of the bulb.

Рис. 4. Labahitha sp. из Филиппин, Mindoro, San Jose (CAS 9060572). А — левая пальпа самца, пролатерально; В - клипеус, спереди. Сокращения: Сp - выступ клипеуса, Су — цимбиум, Еm - эмболюс, $\mathrm{Pl}$ - приэмболюсная мембрана, Тр - тегулярная часть бульбуса.

images of the male clypeus of a putative congener from the Philippines reveals tiny projections (Fig. 4B), as described by Magalhaes (2016: figs 2G, 3E) for Wandella males. When more species of Labahitha nom. n. will be discovered, this hypothesis of a close relationship with Wandella and Yardiella can be tested, and the limits among the three genera clarified. We hope that this re-description of the type species will help in identifying other congeners in the future.

COMPOSITION. Currently monotypic, but several described and undescribed species might prove to be closely allied to L. oonopiformis, including Pritha garciai (Simon, 1892), P. heikkii Saaristo, 1978, P. nicobarensis (Tikader, 1977), and Tricalamus ryukyuensis Ono, 2013. The original descriptions of these species indicate that they have copulatory organs similar to those of L. oonopiformis, but a formal transfer will only be proposed after a direct study of their specimens.

DISTRIBUTION. Known from Malaysia, with at least one putative congener from the Philippines (Fig. $4)$. If the species mentioned above prove to be congeneric, this genus would have a distribution spanning several islands from the Indian and Pacific oceans.

\section{Labahitha oonopiformis (Bristowe, 1938), comb.n.} Figs $1-5$.

Mystes oonopiformis Bristowe, 1938: 319, figs 10-13 (holotype + from Parit Buntar, Perak, Malaysia, leg. H.T. Pagden; should be deposited at the Natural History Museum in London, but is currently lost/untraceable: according to Huber et al. [2014], and Beccaloni [pers. com.]

MATERIAL EXAMINED. MALAYSIA: Neotype $1 \sigma^{\top}$ (MMUE G7572.1100) Pahang Province, Genting, $600 \mathrm{~m}, 26.11 .1990$, J. Murphy \& F. Murphy; 2 + (MMUE G7572.1114) - same, garage wall, $700 \mathrm{~m}, 1.02 .1988 ; 1$ 9, 2 juv. (MMUE G7572.1112) - same, but 18-22.08.1979; 2 juv. (MMUE G7572.1103), "Corley's layang" 21-23.07.1979.
NOTE. Several years ago, when the species was still placed in the Pholcidae, Bernhard Huber (pers. comm.) looked for its holotype without success in the Natural History Museum, London, where Bristowe is known to have deposited some of his types, e.g. that of Thymoites melloleitaoni (Bristowe, 1938) [Levi, 1964]. We recently contacted Janet Beccaloni, the curator at the museum, who said the specimen has remained missing. There is also no evidence of it in the museum's records. Most of other Bristowe's types have been assumed to be lost or destroyed, such as those of Dictyna jacksoni Bristowe, 1935 [Lehtinen, 1967], Callilepsis wiehlei Bristowe, 1935 [Platnick, 1975], Drassodes reimoseri Bristowe, 1935 [Chatzaki et al., 2002] and Dysderina termitophila Bristowe, 1938 [Abrahim et al., 2012], to name a few. Thus, as the holotype of $M$. oonopiformis is currently not deposited in the NHM and there is no evidence that it ever was, we regard the type material of this species to be lost. Considering that the original description is not enough for recognition of the species, we here designate a neotype to maintain stability of the name. The examined specimens come from a locality ca. $240 \mathrm{~km}$ south-east of the type locality of L. oonopiformis. We are confident that our specimens are conspecific with Bristowe's material because they fit his description of a small, pale yellow spider with spineless legs — other species from Malaysia and neighbouring countries either have contrasting colouration or legs with macrosetae.

DESCRIPTION. Male. Measurements. Total length 3.13. Carapace 1.43 long, 1.17 wide, clypeus 0.33 long. Eye sizes and interdistances: ALE 0.126, AME 0.083, PME 0.078, PLE 0.121, PME-PME 0.095. Palp and leg measurements (total length (femur, patella, tibia, metatarsus, tarsus)): palp $-1.47(0.63,0.26$, $0.43,-, 0.15)$; I - $6.36(1.64,0.43,1.79,1.64,0.86)$; II $-4.50: 1.29,0.43,1.14,1.14,0.50)$; III -3.98 

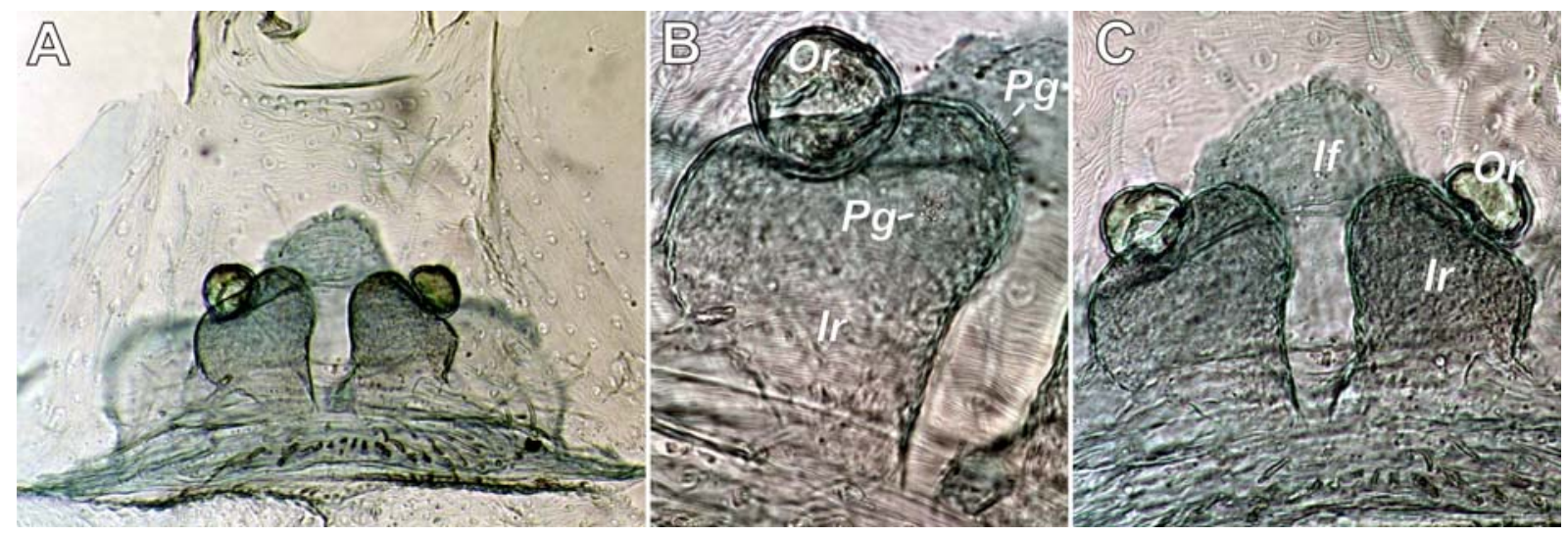

Fig. 5. Endogyne of Labahitha oonopiformis (macerated in $\mathrm{KOH}$ water solution), dorsal, different magnification. Abbreviations: If interpulmonary fold, Ir — inner receptacles, Or — outer receptacles, $\mathrm{Pg}$ - pore glands.

Рис. 5. Эндогина Labahitha oonopiformis сверху (мацерирована в растворе КОН), разные увеличения. Сокращения: If межлёгочная складка, Ir — внутренняя рецептакула, Or — боковая рецептакула, $\mathrm{Pg}$ - железа.

$(1.07,0.40,0.93,1.07,0.51) ; \mathrm{IV}-5.19(1.43,0.47$ $1.29,1.43,0.57)$.

Whole body and legs pale brownish yellow, with only slightly darkened postocular and submarginal areas of carapace, and metatarsi and tarsi I-II. Similarly darkened clypeus with apical unsclerotized region. Eye tubercle brown, eyes with dark-brown bordering, partially fused and forming forward-directed protrusion in front of AME. Abdomen dorsally with almost indistinct and only hardly darker brownish chevron-like pattern. Metatarsus I with an apical, ventro-retrolateral macroseta.

Palp as in Figs 2D, 3. Femur long, longer than tibia+cymbium, not swollen. Patella relatively long, longer than $1 / 2$ of tibia. Tibia not modified, about $2 / 3$ of femur length. Cymbium $(C y)$ short, horseshoe- shaped in anterior view, modified or specialised setae absent. Bulb 3 times longer than wide, its basal or tegular part $(T p)$ globular, as long as wide; with keel-shaped paraembolic lamina $(P l)$ dorsally originated at the level of terminal loop of spermophore $(S p)$; keel about as long as wide, fimbriated, with small triangle, almost indistinct outgrowth; embolic part $(E m)$ long, about 2.5 times longer that tegular part; spermophore with one whole loop, basal part of the loop very wide, terminal part of spermophore gradually tapering.

Female. Measurements. Total length 4.41. Carapace 1.63 long, 1.21 wide, clypeus 0.32 long. Eye sizes and interdistances: ALE 0.111, AME 0.069, PME 0.072, PLE 0.088, PME-PME 0.097. Palp and leg measurements (total length (femur, patella, tibia, metatarsus, tarsus)): palp — $2.53(1.00,0.43,0.46,-, 0.64)$; I $5.93(1.81,0.54,1.50,1.29,0.79)$; II -4.77 (1.36, $0.50,1.20,1.11,0.60)$; III -4.35 (1.21, 0.43, 1.07, 1.07, 0.57); IV - 5.79 (1.64, 0.57, 1.50, 1.49, 0.59).

Colour similar to that in male, but clypeus with larger median pale spot, carapace with less contrasted darkened areas, darker pattern of eye tubercle with less developed anterior protrusion and abdomen with diffuse but distinct brownish chevron-like pattern.
Endogyne as in Fig. 5. Large, membranous inner receptacles $(I r)$ and more sclerotized outer receptacle $(\mathrm{Or})$ originating from mesal side of the inner receptacle. Inner receptacles with conical tip, tip with at least two pore-gland areas $(P g)$ on mesal and dorsal sides. Outer receptacles well separated from inner receptacles, densely covered with pore-glands with cilia longer than 1 radius of the head. Outer receptacles separated by 3 diameters.

DISTRIBUTION. To date, the species is known from the Pahang and Perak Provinces of Malaysia.

ACKNOWLEDGEMENTS. We thank D.V. Logunov (Manchester, UK), L. Esposito, C. Griswold and D. Ubick (San-Francisco, USA) for the loan of material used in this study. We are grateful to B.T. Faleiro and J. Beccaloni for looking for the types of M. oonopiformis in the Natural History Museum (London), and to Naomi Paz (Tel-Aviv University), who kindly copyedited the the final draft. Hirotsugu Ono and an anonymous reviewer generously reviewed the manuscript and provided us with some essential comments which helped to improve this study. Special thanks to Seppo Koponen who arranged the stay of YMM and SLZ in the Zoological Museum, University of Turku. ILFM was supported by a CONICET doctoral fellowship and by grants from CONICET (2012-0943) and FONCyT (2011-1007). SLZ was supported by the Ministry of Absorption, Israel.

\section{References}

Abrahim N., Brescovit A.D., Rheims C.A., Santos A.J., Ott R., Bonaldo A.B. 2012. A revision of the Neotropical goblin spider genus Neoxyphinus Birabén, 1953 (Araneae, Oonopidae) // American Museum Novitates. No.3743. P.1-75.

Bonnet P. 1957. Bibliographia Araneorum. Toulouse: Douladoure. Vol.2. Part 3: G-M. P.1927-3026.

Bristowe W.S. 1938. The classification of spiders // Proceedings of the Zoological Society of London. Ser.B. Vol.108. P.285-322. 
Champion G.C. 1895. On the Heteromerous Coleoptera collected in Australia and Tasmania // Transactions of the Royal Entomological Society of London. Vol.43. P.213-276.

Chatzaki M., Thaler K., Mylonas M. 2002. Ground spiders (Gnaphosidae; Araneae) of Crete (Greece). Taxonomy and distribution. I // Revue suisse de Zoologie. T.109. Fasc.3. P.559-601.

Gray M.R. 1995. Morphology and relationships within the spider family Filistatidae (Araneae: Araneomorphae) // Records of the Western Australian Museum. Suppl. No.52. P.79-89.

Huber B.A., Colmenares P.A., Ramírez M.J. 2014. Fourteen new generic and ten new specific synonymies in Pholcidae (Araneae), and transfer of Mystes Bristowe to Filistatidae // Zootaxa. Vol.3847. N.3. P.413-422.

Legittimo C.M., Simeon E., Di Pompeo P., Kulczycki A. 2017. The Italian species of Pritha (Araneae, Filistatidae): a critical revision and description of two new species // Zootaxa. Vol.4243. N.2. P.201-248.

Lehtinen P.T. 1967. Classification of the cribellate spiders and some allied families, with notes on the evolution of the suborder Araneomorpha // Annales Zoologici Fennici. Vol.4. No.3. P.199-468.

Levi H.W. 1964. The spider genus Thymoites in America (Araneae: Theridiidae) // Bulletin of the Museum of Comparative Zoology at Harvard College. Vol.130. No.7. P.445-471.

Platnick, N. I. 1975. A revision of the Holarctic spider genus Callilepis (Araneae, Gnaphosidae). // American Museum Novitates. No.2573. P.1-32.

Magalhaes I.L.F. 2016. On new or poorly known Australian Filistatidae spiders (Araneae: Araneomorphae), including a study on the fine morphology of Wandella // Journal of Natural History. Vol.50. No.29-30. P.1815-1858

Magalhaes I.L.F., Ramírez M.J. 2017. Relationships and phylogenetic revision of Filistatinella spiders (Araneae: Filistatidae) // Invertebrate Systematics. Vol.31. No.6. P.665-712. doi:10. 1071./IS16083

Marusik Yu.M., Zamani A. 2015. Additional new species of Filistatidae (Aranei) from Iran // Arthropoda Selecta. Vol.24. No.4. P. 429-435.

Ramírez M.J., Grismado C.J. 1997. A review of spider family Filistatidae in Argentina (Arachnida, Araneae), with a cladistic reanalysis of filistatid genera // Entomologica Scandinavica. Vol.28. No.3. P. 319-349.

Zonstein S.L. 2008. The spider genus Zaitunia Lehtinen, 1967 (Araneae: Filistatidae) in Israel and Sinai (Egypt) // Israel Journal of Entomology. Vol.38. P.125-131.

Zonstein S.L., Marusik Yu.M., Koponen S. 2013. Redescription of three species of Filistatidae (Araneae) described by C.F. Roewer from Afghanistan // Zootaxa. Vol.3745. No.1. P.64-72.

Zonstein S.L., Marusik Yu.M., Omelko M.M. 2016. A redescription of the type species of Tricalamus Wang, 1987 (Aranei, Filistatidae) // Zoologicheski Zhurnal. Vol.95. No.5. P.540544.

Zonstein S.L., Marusik Yu.M. 2016. A revision of the spider genus Zaitunia (Araneae, Filistatidae) // European Journal of Taxonomy. Vol.214. P.1-97.

Responsible editor: K.G. Mikhailov 